\title{
Acute Monoblastic Leukemia with Erythrophagocytosis and Absence of KAT6A Rearrangement
}

\author{
Eritrofagositozlu Akut Monoblastik Lösemi ve KAT6A Yeniden Düzenlenme OImaması
}

(D) Carlos De Miguel Sánchez, (D) Diego Robles de Castro, (D) Ana Vega González de Viñaspre, (D) Ariane Unamunzaga Zilaurren, (D) Arantza Mendizábal Abad, (D) José María Guinea de Castro

Hospital Universitario de Álava - Sede Txagorritxu, Department of Hematology, Vitoria-Gasteiz, Spain

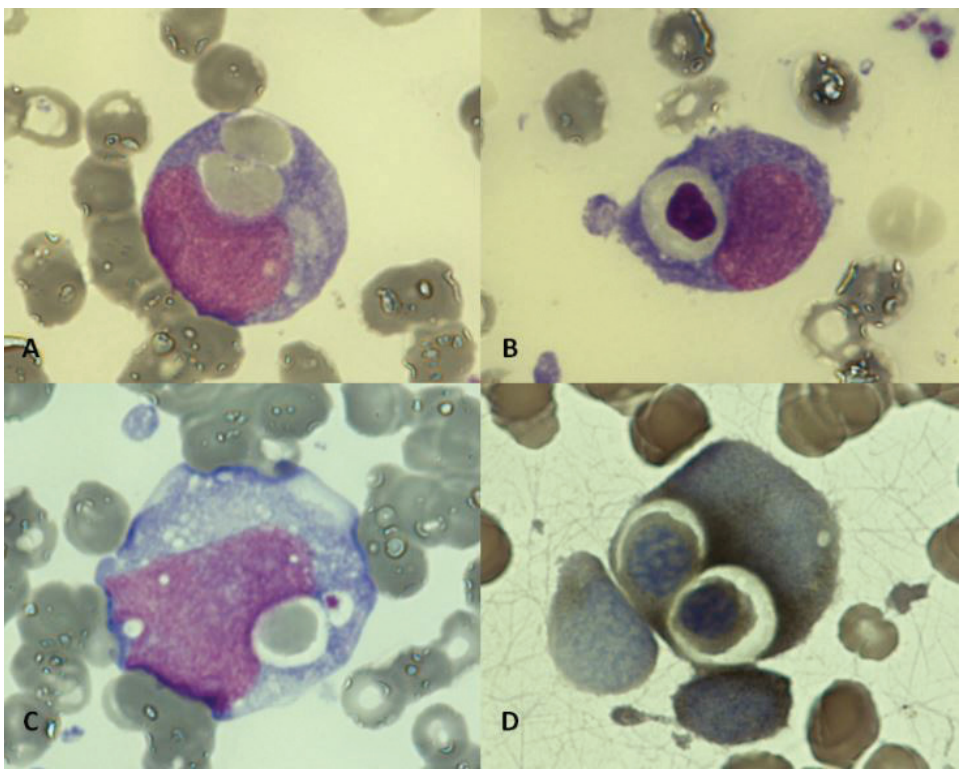

Figure 1. A and B) Erythrophagocytosis was frequently observed in several blasts. C) Hemophagocytosis of platelets. D) Strong alphanaphthyl acetate esterase activity revealed by cytochemical staining.

A 44-year-old woman presented with fever and arthralgia. Her past medical history included ulcerative colitis, which was treated with azathioprine and infliximab. On admission, a full blood count revealed a hemoglobin level of $13 \mathrm{~g} / \mathrm{L}$, leukocyte count of $1.4 \times 10^{9} / \mathrm{L}$, and platelets of $108 \times 10^{9} / \mathrm{L}$. Peripheral blood smear showed $14 \%$ blast cells.
The bone marrow smear was hypocellular and revealed 79\% large blast cells with rounded nuclear contours, fine chromatin with one to three nucleoli, and basophilic cytoplasm, which were compatible with monoblasts. Erythrophagocytosis was frequently observed in several blasts (Figures $1 \mathrm{~A}$ and $1 \mathrm{~B}$ ). Hemophagocytosis of platelets was also observed (Figure 1C). 
Cytochemical staining showed strong alpha-naphthyl acetate esterase activity (Figure 1D). Flow cytometry analysis showed a large blast population with immature monocytoid phenotype (cyMPO \pm , HLADR+, CD14-, CD33+, CD34-, CD64+, and CD117-). Cytogenetic analysis displayed a null karyotype. Molecular analysis with nested RT-PCR was done in order to dismiss KAT6ACREBBP gene rearrangement, which was negative. Bone marrow evaluation after induction chemotherapy showed complete morphological remission and normal karyotype.

Erythrophagocytosis by leukemic blasts is an extremely rare phenomenon and is mostly seen in acute myeloid leukemia, especially associated with monocytic differentiation, $\mathrm{t}(8 ; 16)(\mathrm{p} 11.2 ; \mathrm{p} 13.3) /$ KAT6A-CREBBP, $\mathrm{t}(16 ; 21)(\mathrm{p} 11 ; q 22)$, and inv8(p11q13) $[1,2,3]$. Erythrophagocytosis in the case of monoblastic acute leukemia should prompt exploration for $\mathrm{t}(8 ; 16)(\mathrm{p} 11.2 ; \mathrm{p} 13.3) /$ KAT6A-CREBBP $[1,4]$.

Keywords: Erythrophagocytosis, Acute myeloid leukemia, Monoblast, t(8;16)(p11.2;p13.3)/KAT6A-CREBBP

Anahtar Sözcükler: Eritrofagositoz, Akut myeloid lösemi, Monoblast, t(8;16)(p11.2;p13.3)/KAT6A-CREBBP

\section{Authorship Contributions}

Surgical and Medical Practices: C.M.S., D.R.C., A.V.G.V., A.U.Z., A.M.A., J.M.G.C.; Concept: C.M.S., D.R.C., A.V.G.V., A.U.Z., A.M.A.,
J.M.G.C.; Design: C.M.S., D.R.C.; Data Collection or Processing: C.M.S., D.R.C., A.V.G.V., A.U.Z., A.M.A., J.M.G.C.; Analysis or Interpretation: C.M.S., D.R.C.; Literature Search: C.M.S.; Writing: C.M.S.

Conflict of Interest: The authors of this paper have no conflicts of interest, including specific financial interests, relationships, and/or affiliations relevant to the subject matter or materials included.

Financial Disclosure: The authors declare that this study received no financial support.

\section{References}

1. Gupta A, Reddy GK, Goyal M, Kasaragadda MR. Erythrophagocytosis by blasts in a case of de novo acute monoblastic leukemia with rare but characteristic t $(8 ; 16)$. J Postgrad Med 2017;63:194-196.

2. Olaiya 00, Li W. Frequent erythrophagocytosis by leukemic blasts in B-cell acute lymphoblastic leukemia. Blood 2018;131:2178.

3. Salazar $\mathrm{KL}$, Mosse C. Normal karyotype in a case of acute myeloid leukemia with monocytic differentiation and hemophagocytosis by leukemic blasts. Lab Med 2015;46:64-68.

4. Montewis A, Eveillard M. Acute myeloid leukemia with erythrophagocytosis indicative of KAT6A rearrangement. Blood 2016;128:314. 